\title{
ANALISIS TREND KINERJA KEUANGAN PERBANKAN SYARIAH TAHUN 2015 SAMPAI DENGAN 2017
}

\author{
Andri Veno \\ E-mail : veno.focus@gmail.com \\ Syamsudin \\ FEB Univ. Muh. Surakarta \\ E-mail : syamsudin_ums@yahoo.co.id
}

\begin{abstract}
Trend analysis is a method of statistical analysis that is intended to make an estimate or forecast the future. To do a good forecasting is needed various kinds of information (data) is quite a lot and observed in a period of relatively long, so that the analysis can determine how many big fluctuations and the factors that influence those change. The profitability ratios will provide an overview of the effectiveness of the management of the company. The greater the profitability means the better, because the prosperity of the owner of the company increased with greater profitability. Profitability ratios consist of Profit Margin, Basic Earning Power, Return on Assets and Return on Equity .
\end{abstract}

Keyword : Trend Analysis, Profitability ratio, Return on Equity

\section{A. Pendahuluan}

Syariah Islam merupakan pandangan hidup yang seimbang dan terpadu, diciptakan untuk mengantarkan manusia menuju kebahagiaan di dunia dan akhirat (falah) melalui penegakan berbagai seruan yang telah kodifikasikan dalam Al-Qur'an dan As-Sunnah. Aturan yang terdapat dalam Al-Qur'an dan As-Sunnah tersebut mengatur manusia dalam 
berbagai aspek. Keuangan yang berlabel syari'at terus mengalami perkembangan dalam skala besar dengan menawarkan produk-produknya yang beraneka ragam dengan istilah-istilah berbahasa Arab. Banyak masyarakat yang masih bingung dengan istilah-istilah tersebut dan masih ragu apakah benar semua produk tersebut adalah benar-benar jauh dari pelanggaran syari'at ataukah hanya rekayasa semata. Pembiayaan berdasarkan prinsip syariah merupakan usaha pokok dari bank yang beroperasi secara syariah. Pada dasarnya pembiayaan dapat mengakibatkan risiko kegagalan, di mana risiko tersebut dapat disebut dengan financing risk. Kesalahan dalam pemberian pembiayaan dapat mengakibatkan pembiayaan bermasalah.

Didalam Al-quran telah disebutkan tentang hukum riba diantaranya tafsir An- Nisa' ayat 161 "[4:161] dan disebabkan mereka memakan riba, padahal sesungguhnya mereka telah dilarang daripadanya, dan karena mereka memakan harta benda orang dengan jalan yang batil. Kami telah menyediakan untuk orang-orang yang kafir di antara mereka itu siksa yang pedih". Tarsiran yang lain Ali Imran Ayat 130 " [3:130] Hai orang-orang yang beriman, janganlah kamu memakan riba dengan berlipat ganda dan bertakwalah kamu kepada Allah supaya kamu mendapat keberuntungan", dan masih banyak lagi tafsiran yang lain tentang hukum simpan pinjam. Tafsiran tersebut menjadi ajuan bagi perusahaan ataupun perbankan dalam menjalankan usahanya untuk mencapai keadilan dan kinerja yang optimal sesuai hukum Islam.

Dalam menilai kinerja suatu perusahaan maka salah satunya dapat di ambil dari gambaran Profitabilitas dimana tingkat kemampuan perusahaan dalam menghasilkan suatu pendapatan maupun pemasukan yang tercermin dalam laba perusahaan, pihak manajemen selaku pelaksana dari suatu perusahaan mempunyai tanggung jawab akan berlangsungnya operasi perusahaan. Selain itu pihak manajemen mempunyai tanggung jawab yaitu tanggung jawab untuk memperoleh dana untuk membiayai aktiva dan tanggung jawab untuk menggunakan aktiva yang dimiliki perusahaan dalam rangka 
memperoleh penghasilan (Prastowo, 2002:38). Tingkat profitabilitas yang dihasilkan oleh perusahaan seringkali menjadi bahan pertimbangan investor dalam pilihan investasinya. Berapa besar laba yang dapat dihasilkan oleh perusahaan menjadi faktor penting dalam ukuran keberhasilan kinerja pihak manajemen.

Menurut Ibrahim (2003), untuk mengetahui prospek usaha dari proyek yang direncanakan perlu diadakan peramalan tentang peluang pasar dari produk yang dihasilkan. Peluang pasar merupakan aspek yang sangat penting untuk diperhatikan karena tanpa adanya pemasaran dari produk yang dihasilkan, tidak ada artinya suatu usaha dilanjutkan. Peramalan mempunyai pengertian sebagai perkiraan atau dugaan terhadap sesuatu yang akan terjadi di masa yang akan datang dengan berdasar pada kejadiankejadian di masa lalu yang dianalisis secara ilmiah khususnya dengan menggunakan metode statistik.

Hasil peramalan atau perkiraan juga dapat digunakan sebagai informasi dalam mengukur tentang besar kecilnya kapasitas produksi yang direncanakan. Semakin kecil kapasitas produksi dibandingkan dengan peluang pasar yang tersedia maka semakin besar kemungkinan tingkat keberhasilan. Sebaliknya, semakin besar kapasitas produksi dibandingkan dengan peluang yang tersedia semakin kecil kesempatan untuk mendirikan atau mengembangkan suatu usaha.

Salah satu peralatan statistik yang dapat digunakan untuk memperkirakan keadaan suatu usaha di masa yang akan datang berdasarkan data masa lalu adalah trend. Trend merupakan peramalan suatu variabel dengan variabel bebasnya waktu atau gerakan dari deret berkala selama beberapa tahun dan cenderung menuju pada suatu arah, dimana arahnya dapat naik, mendatar, maupun menurun (Ibrahim, 2003). Peramalan merupakan penyambungan dari garis trend melewati waktu dari 
pengamatan terakhir sampai dengan waktu untuk peramalan dibuat.

Berdasarkan uraian diatas tujuana penelitian ini akan mengulas tentang trend, Dengan menganalisa Profitabilitas Pembiyaaan Syariah di Indonesia. Perkembangan Profitabilitas Pembiyaaan Syariah di Indonesia dapat diproyeksikan pada jangka panjang dengan menggunakan analisis trend (least square method). Garis trend ini akan dapat menggambarkan perkembangan Profitabilitas (ROE).

\section{B. Landasan Teori}

\section{Perbankan Syariah}

Karim (2006) menyatakan bahwa pembiayaan musyarakah merupakan semua bentuk usaha yang melibatkan dua pihak atau lebih dimana mereka secara bersama-sama memadukan seluruh bentuk sumber daya baik yang berwujud maupun tidak berwujud.Keuntungan dan kerugian ditanggung bersama sesuai dengan proporsi yang telah ditetapkan sebelumnya,Melalui pembiayaan bagi hasil yang disalurkan,bank syariah akan memperoleh pendapatan berupa bagi hasil yang menjadi bagian bank.

Dari pengelolaan pembiayaan murabahah, bank syariah memperoleh pendapatan sesuai dengan nisbah yang telah disepakati dengan nasabah (Muhammad, 2005). Pendapatan yang diperoleh akan mempengaruhi besarnya laba yang diperoleh bank. Besarnya laba yang diperoleh bank syariah akan mampu mempengaruhi profitabilitas yang dicapai. Perbankan berperan dalam mempermudah proses pengalihan dana dari pihak yang kelebihan dana pada pihak yang membutuhkan dana, untuk melakukan proses tersebut, perbankan menghimpun dana dari masyarakat yang memiliki kelebihan dana dan menyalurkan dana tersebut kembali kepada masyarakat yang membutuhkan dana tersebut untuk kegiatan yang lebih produktif. Peran tersebut membuat perbankan disebut sebagai lembaga perantara keuangan (financial intermediary institusion). Menurut dari segi imbalan 
maupun jasa atas penggunaan dana, simpanan ataupun pinjamannya, bank dibedakan menjadi dua, yaitu bank konvensional dan bank syariah.

Bank konvensional adalah bank yang dalam aktivitasnya, baik penghimpunan dana maupun dalam rangka penyaluran dananya, memberikan dan mengenakan imbalan berupa bunga atau sejumlah imbalan dalam persentase tertentu dari dana untuk suatu periode tertentu, sedangkan bank Syariah adalah bank yang dalam aktivitasnya, baik penghimpunan dana maupun dalam rangka penyaluran dananya memberikan dan mengenakan imbalan mengacu pada hukum Islam, dan dalam kegiatannya tidak membebankan bunga, maupun tidak membayar bunga kepada nasabah. Imbalan yang diterima oleh bank syariah, maupun yang dibayar nasabah tergantung dari akad dan perjanjian antara nasabah dan pihak bank (Ismail, 2010).

Perbankan menurut jenis operasionalnya terbagi menjadi dua yaitu meliputi. Bank konvensional adalah bank yang dalam operasionalnya menerapkan metode bunga, karena metode bunga sudah ada terlebih dahulu, menjadi kebiasaan dan telah dipakai secara meluas dibandingkan dengan metode bagi hasil. Bank konvensional pada umumnya beroperasi dengan mengeluarkan produk-produk untuk menyerap dana masyarakat dan menyalurkan dana yang telah dihimpun dengan cara mengeluarkan kredit.

Sedangkan bank syariah adalah bank yang beroperasi sesuai dengan prinsip-prinsip syariah Islam, maksudnya adalah bank yang dalam operasinya mengikuti ketentuanketentuan syariah Islam, khususnya yang menyangkut tata cara bermuamalah secara Islam. Kegiatan bank syariah dalam hal penentuan harga produknya sangat berbeda dengan bank konvensional. Penentuan harga bagi bank syariah didasarkan pada kesepakatan antara bank dengan nasabah penyimpan dana sesuai dengan jenis simpanan dan jangka waktunya, yang akan menentukan besar kecilnya porsi bagi hasil yang akan diterima penyimpan. Dalam rangka menjalankan kegiatannya, 
bank syariah harus berlandaskan pada Al-Qur'an dan hadits. Bank syariah mengharamkan penggunaan harga produknya dengan bunga tertentu. Bagi bank syariah, bunga bank adalah riba.

Dasar hukum restrukturisasi pembiayaan,secara umum adalah Pasal 36 UU Perbankan Syariah, dan secara khusus adalah Pasal 2 ayat(1) PBI No. 10/18/PBI/2008 dan Butir I angka 4 SEBI No. 10/34/DPBS/2008, Perihal Restrukturisasi Pembiayaan bagi Bank Umum Syariah dan Unit Usaha Syariah. Berdasarkan Pasal 36 UU Perbankan Syariah dan Pasal 2 ayat (1) PBI No. 10/18/PBI/2008, serta Butir I angka (4) SEBI No. 10/34/DPBS/2008, prinsip-prinsip restrukturisasi pembiayaan murabahah harus memperhatikan beberapa hal. Pertama, prinsip tidak merugikan bank dan nasabah, dimana bank melakukan restrukturisasi pembiayaan maupun kegiatan usaha harus dilakukan dengan cara-cara yang tidak merugikan bank syariah dan nasabah. Kedua, prudential principle, dimana bank syariah mempunyai keyakinan atas kemauan dan kemampuan nasabah untuk melunasi kewajiban pada waktunya

\section{Kinerja Perusahaan}

Perusahaan sebagai salah satu bentuk organisasi pada umumnya memiliki tujuan tertentu yang ingin dicapai dalam usaha untuk memenuhi kepentingan para stake holder. Adapun tujuan perusahaan antara lain untuk memperoleh keuntungan (profit), meningkatkan nilai perusahaan dan untuk memuaskan kebutuhan masyarakat. Tercapainya tujuan tersebut ditentukan oleh kinerja yang nantinya dapat dijadikan sebagai dasar pengambilan keputusan baik pihak internal maupun eksternal.

Tingkat profitabilitas digunakan sebagai dasar untuk mengukur kinerja keuangan perusahaan, hal ini dilakukan mengingat daya tarik bisnis (business attractiveness) merupakan salah satu indikator penting dalam persaingan usaha, sedangkan indikator daya tarik bisnis dapat diukur dari profitabilitas usaha, seperti ROA, ROE dan NPM. Semakin 
tinggi rasio ini akan menarik pendatang baru untuk masuk dalam dunia usaha, sehingga pada kondisi persaingan tersebut akan membuat rate of return cenderung mengarah pada keseimbangan (Gale, 1972). Daya tarik bisnis yang semakin tinggi akan mendorong pendatang baru untuk masuk dalam dunia usaha sehingga laba abnormal lambat laun akan kembali menurun menuju laba normal. Return On Equity (ROE) merupakan rasio yang menunjukkan kemampuan perusahaan dalam menghasilkan laba bersih untuk pengembalian ekuitas pemegang saham. Return On Equity (ROE) merupakan rasio keuangan yang digunakan untuk mengukur tingkat profitabilitas dari ekuitas. Semakin besar hasil ROE maka kinerja perusahaan semakin baik.

Rasio yang meningkat menunjukkan bahwa kinerja manajemen meningkat dalam mengelola sumber dana pembiayaan operasional secara efektif untuk menghasilkan laba bersih (profitabilitas meningkat). Jadi dapat dikatakan bahwa selain memperhatikan efektivitas manajemen dalam mengelola investasi yang dimiliki perusahaan, investor juga memperhatikan kinerja manajemen yang mampu mengelola sumber dana pembiayaan operasional secara, efektif untuk menciptakan laba bersih. Purnomo (1998) dalam Itan dan Syakhroza (2003) menyatakan bahwa harga saham memiliki kepekaan terhadap perubahan ROE.

Rasio Profitabilitas adalah rasio yang menggambarkan kemampuan perusahaan untuk menghasilkan keuntungan dengan menggunakan modal yang tertanam didalamnya. Rasio profitabilitas Return on Equity (ROE). Rasio ini mengukur kemampuan perusahaan memperoleh laba yang tersedia pemegang saham perusahaan. Return on Equity (ROE) dihitung dengan menggunakan rumus:

Return on Equity $(\mathrm{ROE})=\frac{\text { Lababersih }}{\text { ModalSendiri }}$ 


\section{Analisis Trend}

Analisis trend merupakan suatu metode analisis statistika yang ditujukan untuk melakukan suatu estimasi atau peramalan pada masa yang akan datang. Untuk melakukan peramalan yang baik maka dibutuhkan berbagai macam informasi (data) yang cukup banyak dan diamati dalam periode waktu yang relatif cukup panjang, sehingga hasil analisis tersebut dapat mengetahui sampai berapa besar fluktuasi yang terjadi dan faktor-faktor apa saja yang mempengaruhi terhadap perubahan tersebut.

Secara teoritis, dalam analisis runtun waktu (time series) hal yang sangat menentukan adalah kualitas dan keakuratan dari data-data yang diperoleh serta waktu atau periode dari data-data tersebut dikumpulkan. Jika data yang dikumpulkan tersebut semakin banyak maka semakin baik pula estimasi atau peramalan yang diperoleh. Sebaliknya, jika data yang dikumpulkan semakin dengan jumlah sedikit maka hasil estimasi atau peramalannya akan semakin jelek. Karena pada dasarnya semakin banyak data maka semakin bagus tingkat kesimpulannya.

\section{Metodologi Penelitian}

\section{Jenis dan Sumber data}

Jenis data yang digunakan dalam penelitian ini adalah data sekunder. Data yang berupa rasio keuangan bank pembiayaan syariah, hasil olahan laporan keuangan Bank pembiayaan Syariah periode 2008-2014 yang telah diaudit dan kemudian dipublikasikan. Peneliti menggunakan data Time series dari tahun 2009 sampai tahun 2014. Yang diterbitkan oleh bank Indonesia dengan laporan statistik perbankan Syari'ah

\section{Teknik Analisis Data}

Analisis data kuantitatif, yaitu metode analisa data yang ada hubungannya dengan rumus-rumus dan angka-angka yang berhubungan dengan analisa rasio keuangan : Menghitung rasio keuangan Bank Pembiayaan Rakyat Syariah 
tentang rasio profitabilitas (2) Membuat tabel rasio keuangan Bank Pembiayaan Rakyat Syariah; (3) Menganalisisis rasio profitabilitas keuangan Bank Pembiayaan Rakyat Syariah dengan menggunakan time series analysis; dan (4) Menyimpulkan hasil analisis

Metode yang dapat digunakan untuk analisis time series ini adalah: Metode Least Square Persamaan garis linier dari analisis time series adalah:

$y=a+b x$

Keterangan :

y adalah variabel dependen (tak bebas) yang dicari trendnya.

$x$ adalah variabel independen (bebas) dengan menggunakan waktu (biasanya dalam

tahun).

Sedangkan untuk mencari nilai konstanta a dan b dapat dipakai persamaan:

$\mathrm{a}=\frac{\sum y}{N}$ dan $\mathrm{b}=\frac{\sum x y}{x^{2}}$

\section{Hasil Penelitian dan Pembahasan}

Profitabilitas adalah kemampuan menghasilkan laba (profit) selama periode tertentu dengan menggunakan aktiva yang produktif atau modal, baik modal secara keseluruhan maupun modal sendiri (Van Horn dan Wachowiez, 1997:148149). Pendapat lain menyebutkan bahwa profitabilitas perusahaan merupakan salah satu indikator yang tercakup dalam informasi mengenai kinerja perusahaan jangka panjang. Kinerja keuangan tersebut dapat dilihat melalui analisis laporan keuangan.

Menurut Brigham dalam bukunya "Managerial Finance" mengemukakan profitabilitas sebagai berikut : "Profitability is the result of a large number of policies and decision". 
Sartono (2001:119) mendefinisikan profitabilitas sebagai kemampuan perusahaan memperoleh laba dalam hubungan dengan penjualan, total aktiva produktif maupun modal sendiri. Rasio profitabilitas ini akan memberikan gambaran tentang tingkat efektifitas pengelolaan perusahaan. Semakin besar profitabilitas berarti semakin baik, karena kemakmuran pemilik perusahaan meningkat dengan semakin besarnya profitabilitas. Rasio profitabilitas terdiri atas Profit Margin, Basic Earning Power, Return On Assets, dan Return On Equity. Untuk Penelitian Mengambil salah satu gambaran Profitabilitas dengan Return On Equity.

\section{Metode Least Square}

Forecast dengan metode least square dapat dihitung dengan rumus :

Tabel 1.

Rasio Keuangan Bank Pembiayaan Rakyat Syariah (ROE)

\begin{tabular}{|c|c|c|c|c|c|}
\hline $\begin{array}{c}\text { Periode } \\
\text { Waktu } \\
\text { Tahuan }\end{array}$ & $\begin{array}{c}\text { Rasio } \\
\text { ROE }\end{array}$ & $\boldsymbol{X}$ & $\boldsymbol{X} \boldsymbol{y}$ & $\boldsymbol{X}^{2}$ & $\boldsymbol{T}$ \\
\hline 2008 & $14,77 \%$ & -3 & $-44,31$ & 9 & 1 \\
\hline 2009 & $21,55 \%$ & -2 & $-43,10$ & 4 & 2 \\
\hline 2010 & $14,29 \%$ & -1 & $-14,29$ & 1 & 3 \\
\hline 2011 & $18,95 \%$ & 0 & 0 & 0 & 4 \\
\hline 2012 & $20,54 \%$ & 1 & 20,54 & 1 & 5 \\
\hline 2013 & $21,22 \%$ & 2 & 42,44 & 4 & 6 \\
\hline 2014 & $16,13 \%$ & 3 & 48,39 & 9 & 7 \\
\hline Jumlah & 127,45 & & 9,67 & 28 & \\
\hline
\end{tabular}

Sumber : Bank Indonesia Statistik Perbankan Syariah Desember 2014 
Persamaan Garis Trend

$\mathrm{Y}=\mathrm{a}+\mathrm{bX}$

Dimana :

$\mathrm{a}=\frac{\sum y}{N}$ dan $\mathrm{b}=\frac{\sum x y}{x^{2}}$

$\mathrm{a}=(127,45 / 7) \quad \mathrm{a}=18,207$

$\mathrm{b}=(9,67 / 28) \quad \mathrm{b}=0,345$

a. Persamaan garis trendnya adalah :

$$
\begin{aligned}
& Y=a+b X \\
& Y=18,207+0,345 X
\end{aligned}
$$

b. Perkiraan Rasio Keuangan ROE Tahun 2015

$\mathrm{Y}=\mathrm{a}+\mathrm{bX}$

$Y=18,207+0,345 X$

Nilai $X$ tahun 2015 adalah 8 maka,

$\mathrm{Y}=18,207+0,345(8)$

$\mathrm{Y}=18,207+2,76$

$\mathrm{Y}=20,067 \%$

Artinya peramalan Rasio Keuangan Bank Pembiayaan Rakyat Syariah untuk ROE pada tahun 2015 diperkirakan sebesar 20,067 \%

c. Perkiraan Rasio Keuangan ROE Tahun 2016

$\mathrm{Y}=\mathrm{a}+\mathrm{bX}$

$\mathrm{Y}=18,207+0,345 \mathrm{X}$

Nilai $X$ tahun 2016 adalah 9 maka,

$Y=18,207+0,345(9)$

$Y=18,207+3,105$

$\mathrm{Y}=\mathbf{2 1 , 3 1 2 \%}$

Artinya Rasio Keuangan Bank Pembiayaan Rakyat Syariah untuk ROE pada tahun 2016 diperkirakan sebesar 21,312 \%

d. Perkiraan Rasio Keuangan ROE Tahun 2017

$\mathrm{Y}=\mathrm{a}+\mathrm{bX}$

$Y=18,207+0,345 X$

Nilai $X$ tahun 2016 adalah 10 maka,

$\mathrm{Y}=18,207+0,345$ (10)

$\mathrm{Y}=18,207+3,45$ 
Analisis Trend Kinerja Keuangan Perbankan Syariah Tahun 2015...

$Y=21,657 \%$

Artinya Rasio Keuangan Bank Pembiayaan Rakyat Syariah untuk ROE pada tahun 2017 diperkirakan sebesar $21,657 \%$

Tabel 2.

Angka Trend dari tahun 2015-2017

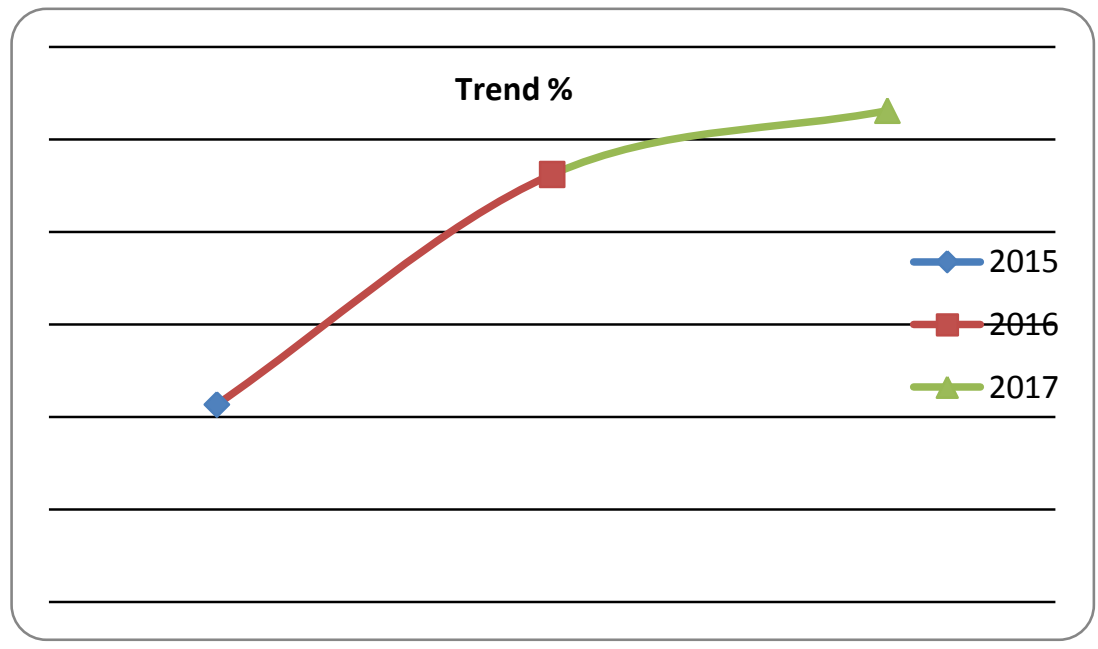

Untuk angka rasio keuangan ROE pada tahun 2008 sampai 2014 yang paling tinggi adalah pada tahun 2009 yaitu sebesar 21,55 \% sedangkan rasio terendah di tahun 2008 yaitu 14,77 \%. Sedangkan untuk trend (Peramalan) kenaikan rasio keungan bank pembiayaan rakyat syariah pada tahun 2015 mengalami kenaikan 3,937 \% dibandingkan tahun 2014, untuk tahun 2016 mengalami kenaikan 1,245 \% dibandingkan 2015, untuk tahun 2017 yang akan datang 0,345 \% dibandingkan tahun 2016.

\section{E. Simpulan dan saran}

\section{Simpulan}

Berdasarkan uraian pembahasan diatas maka dapat disimpulkan bahwa : 
a) Kinerja perbankan syariah tahun 2008-2014 cenderung meningkat dari segi profitabilitas rasio keuangan REO dengan angka tertinggi di tahun 2009

b) Trend peramalan Kinerja perbankan syariah tahun 20152017 juga terus mengalami pertumbuhan dari segi profitabilitas rasio keuangan REO dengan prediksi paling tinggi di tahun 2016

c) Dengan tingkat rasio keuangan perbankan syariah yang mengalami kencenderungan meningkat maka harapan bagi rakyat Indonesia yang mayoritas muslim untuk berinvestasi secara syariah menurut hukum Islam menjadi semakin percaya dengan kinerja perbankan secara syariah.

\section{Saran}

a) Untuk gambaran kinerja perbankan syariah berdasarkan profitabilitas mengunakan proksi selain Return on Equity (ROE) yaitu Profit Margin, Basic Earning Power, Return On Assets sehingga dapat mengeneralisasi gambaran profitabilitas secara keseluruhan

b) Trend Kinerja perbankan syariah hanya ditahun 2015-2017 sehingga tidak dapat mengetahui trend 10 tahun yang akan datang agar memberikan kenyakinan kepada nasabah yang mengingikan secara syariah

c) Penelitian selanjutnya dapat membandingkan rasio kinerja keuangan perbankan konvensional sehingga mendapatkan perbedaan prosentase profitabilitas rasio keuangan. 
Analisis Trend Kinerja Keuangan Perbankan Syariah Tahun 2015...

\section{Daftar Pustaka}

Bank Indonesia, Desember 2014, Statistik Perbankan Syariah,. Di akses 11 April 2016

Direktorat Perbankan Syariah Bank Indonesia,2008, “Kodifikasi Produk Perbankan Syariah" tersedia di website: http:/ / www.bi.go.id/NR/rdonlyres/6FBBF37CB3074E64-B8195DA1B5FF5EAE/14712/ Kodifikasi Produk Perbankan Syariah Lampiran SE. pdf, diakses tanggal 13 Mei 2016

Ismail. 2011. Perbankan Syariah. Jakarta: Kencana.

Kasmir. 2006. Manajemen Perbankan. Jakarta: PT Raja Grafindo Persada.

Muhammad. 2005. Manajemen Bank Syariah. Yogyakarta: UPP AMPYKPN.

Nur Mawaddah, 2015 "faktor-faktor yang mempengaruhi profitabilitas Bank syariah Jurnal Etikonomi Volume 14 (2), Oktober 2015

Yoyo, Purnomo,1998. Ketertarikan Kinerja Keuangan dengan Harga Saham, Usahawan, Desember No.12. Tahun XXVII 